\title{
低レイノルズ数領域でのプロペラブレード表面の 圧力とタフト測定に基づく流体解析*1 \\ Fluid Analysis by the Pressure and Tuft Measurement on the Propeller Blade Surface in the Field of Low Reynolds Number
}

\author{
新 井啓 之*2 ·平 岡 克 己*3 \\ Nobuyuki Arai and Katsumi HiRaOKA
}

Key Words : Fluid Dynamics, Viscous Flows, Wings and Airfoil Section, Testing

\begin{abstract}
The influence of propeller blade wake is emphasized at the performance design of propeller. The propeller wakes mainly consist of the wing tip vortex generated at the tip of blade and the vortex sheet from the trailing edge of the blade, which describe the helix in the wake. The source of these wakes is the surface of the blade, so the conditions of the flow on the surface are largely concerned with formation of the wake and the performance of propeller. Then the propeller blade was made under the condition of low Reynolds number flow, and the flow on surface is studied by empirical means of direct pressure measurement and tuft method. An exist of separation flow was revealed by the pressure measurement and the appearance of the cross flow on the blade could be observed by tuft method.
\end{abstract}

\section{1. は じめ に}

プロペラ駆動による推進は, 低速での推進機構としては 極めて効率が高く，かつ長い歴史を持つ. 人力飛行機用の ブレードに関する研究も進められ，低レイノルズ数領域で のプロペラの活用の場は少なくない，また，近年では，環 境問題に対する社会意識の顕在化に伴い風力発電に注目が 集まっており，多様な気候風土に対応した風車ブレードの 開発が盛んになっている。

プロペラやローター利用の起源は, 古くは古代中国での 羽根の玩具や，ダ・ビンチによるアルキメデス・スクリュー を応用した垂直浮揚機など，多くの人が知るところである. また，19 世紀後半からプロペラの性能計算に関する理論が 発展し始め, 最も単純な理論としては, 軸流方向に対する運 動量理論1) が Rankin ${ }^{2)}$, Froude ${ }^{3)}$ らにより提唱された。プ ロペラをアクチュエータに置き換えて運動量とエネルギー 保存の概念を元に, 現在においてもスクリュー推進の推力 や理論上の最大効率を知る手段として広く用いられている. しかしながら，単純な運動量理論の仮定により，プロペラ 後流の回転方向の動きやブレードの形状抵抗などの損失は 考慮されていない. また, 翼素理論4)では翼素に働く揚力. 抗力をブレード全体にわたり積分することでブレード全体 の推力・抗力を得る手法であり, 後の運動量-翼素理論5) と

\footnotetext{
*1 C) 2009 日本航空宇宙学会

平成 20 年 6 月 14 日原稿受理

*2 東海大学情報教育センター

$* 3$ 東海大学工学部航空宇宙学科
}

ともに吹き下ろし速度による誘導迎え角が考慮されている. さらに，プロペラ回転面から十分後流での渦層の螺旋面を 考慮した渦理論5) では, デイスク荷重が軽い場合, 後流の 渦層が剛体として流れるときエネルギー損失が最小となる Betz $^{6)}$ の条件や，有限なブレード枚数による後流での螺旋 面密度の違いに起因する半径方向の流れによる効果を考慮 した Prandtl7)の Tip loss factor などから，ブレード設計 に対してより現実に近い解が得られるようになった。

プロペラの形状設計法としては, Larrabee ${ }^{8)}$ を経て, プ ロペラ後流に一様な螺旋流を仮定しディスク面でのエネル

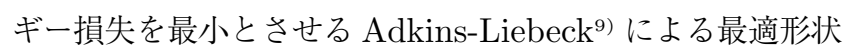
設計法が提案され，低レイノルズ数領域で使用するプロペ ラブレード設計法として用いられている。 また，近年，後 流渦法による後流予測法もプロペラブレードや風車ブレー ドに対し用いられている。

ブレードの設計において，ブレード表面での流れ，及び プロペラ後流, すなわち縮流, 翼端渦, 渦層の移動がその 性能を決定する上で極めて重要である。本実験では, 低レ イノルズ数領域に適した断面翼型を有するプロペラブレー ド周りに関する各種測定を行い, 設計值との比較, またブ レード表面の流れの様子について, 実験に基づいた考察を 行う. 計測は, 推力・トルク測定, また, 回転中のブレー ド周りの流れに関する計測として，ブレード表面の圧力測 定，タフトによるブレード表面の流向調査を行った。これ まで，プロペラ表面での様子を，実験的に明らかにした例 は少ない。 そこで今回これらを 1 つのブレードの, 表面の 流れの状態を多角的視野から総合的に評価する. 


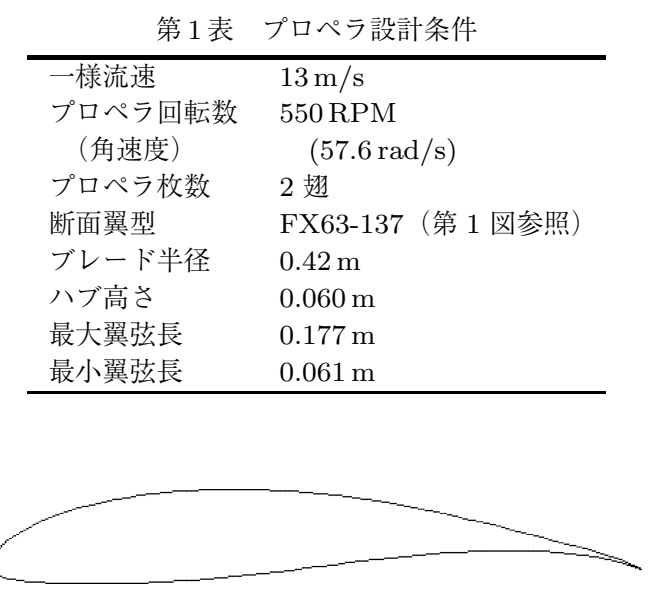

第1図 FX63-137 翼型

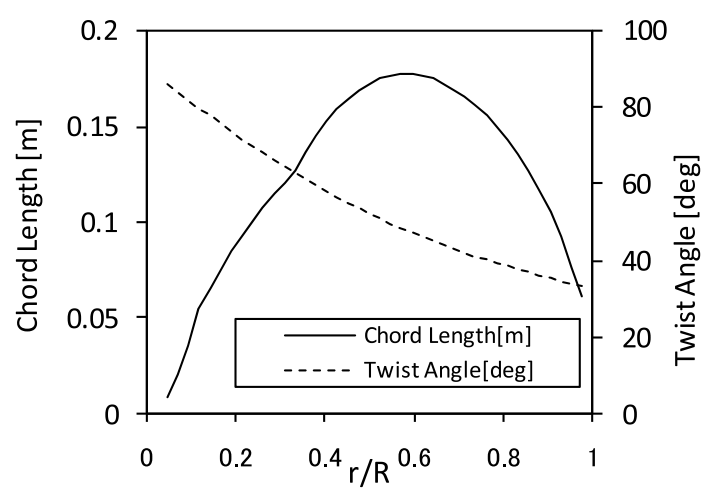

第 2 図 Prop00 の捻り角度, 及び翼弦長

\section{2. ブレード設計・製作}

低レイノルズ数領域下でのブレード設計には前述の Adkins-Liebeckによる最適形状設計法9)を使用した。こ の手法では, 進行速度 $V(\mathrm{~m} / \mathrm{s})$, プロペラ回転角速度 $\omega(\mathrm{rad} / \mathrm{s})$, ブレード半径 $R(\mathrm{~m})$, 及びブレード枚数などか ら, Prandtlの運動量損失関数を加味した循環分布を元に, ブレード半径位置ごとの $R e$ 数から, 各半径位置での翼断 面における $C_{\mathrm{D}} / C_{\mathrm{L}}$ 值が最小となるように逐次計算を繰り 返すことにより，ブレードの迎え角（ねじり角）分布と翼 弦長分布を決定することができる。本実験に用いるプロペ ラ設計にあたり，以下の点を考慮した。

・広範囲な迎え角に対して高い揚力を維持する翼型を断面 形状に用いる。

·圧力測定のための十分な面積を確保するために, 翼弦長 を長くする。

・低レイノルズ数でのプロペラの特性を見るために，プロ ペラ半径方向の $80 \%$ 位置においてのレイノルズ数を $10^{5}$ 以上とする.

プロペラの風洞実験は東海大学航空宇宙学科所有の低速 風洞で行うため, プロペラブレードのブレード長は風洞測 定部に伴う制約を受け，直径を $0.84 \mathrm{~m}$ とした．設計には第 1 表のパラメータを用いた。

またここの手法を利用するにあたり，翼断面形として
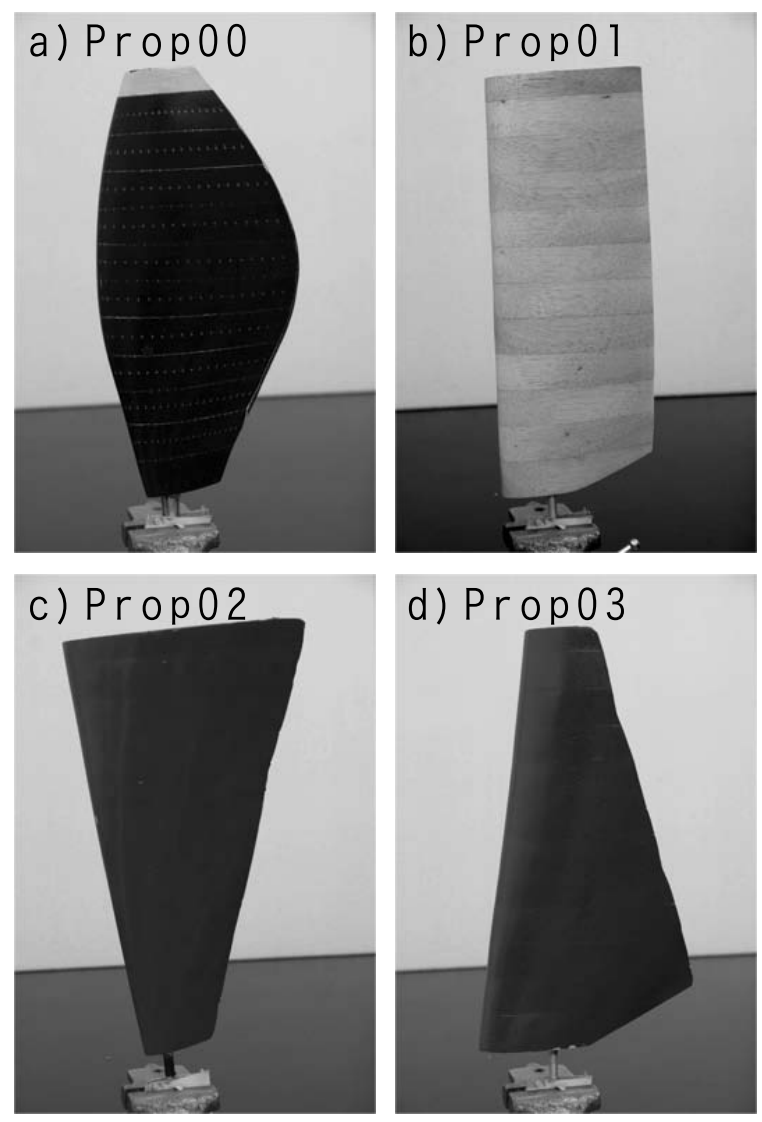

第 3 図 測定用プロペラブレード

FX63-137 翼型を用いた (第 1 図).この翼型は $R e$ 数 $10^{5}$ 領域において良好な揚抗比特性を持つ. また逐次計算で必 要となる $R e$ 数及び迎え角をパラメータとして持つ $C_{\mathrm{L}}$ 及 び $C_{\mathrm{D}}$ についての関数は, 2 次元パネル法を利用したソフ トウェアXFOIL を用いて算出した。

同手法により得られたブレードのねじり角と翼弦長を第 2 図に示す。図中のねじり角はプロペラのディスク面から 翼弦線のなす角度である。後述の圧力測定での “取り付け 角度 0 度”は，この設計值のブレード取り付け角度である. また，設計での最適条件である “一様流速 $13 \mathrm{~m} / \mathrm{s}$, 回転数 550 RPM”での測定環境を「標準状態」と呼ぶものとする.

第 3 図 (a) に示したものは, 最適形状設計法を用いて設 計・製作したブレードである (Prop00).ブレードは，バル サ材を用いて作成した。表面にはニスを塗布し研磨するこ とで表面荒さを極力抑えている。

また，このブレードとは別に，トルク測定・圧力測定な どで, 平面形状の相違による定性的な比較を行うため, 平 面形状のみ異なる 3 種類のブレード（Prop01，02，03） を, Prop00 ブレードと同一の剛率とねじり角で製作した. Prop01 の平面形状は, 全ブレード半径方向において翼弦 長一定の矩形（第 3 図 (b)), Prop02 はブレード根側から ブレード端側に向かって翼弦長が線形変化で増加する先太 りの台形（第 3 図 (c)), Prop03 は, 逆に, ブレード根側 からブレード端側に向かって翼弦長が線形変化で減少する 先細りの台形（第 3 図 $(\mathrm{d})$ ) となっている. 


\begin{tabular}{|c|c|}
\hline 形式 & 単帰路式回流型低速風洞 \\
\hline 最大風速 & $40 \mathrm{~m} / \mathrm{s}$ \\
\hline 風洞出口面積 & $1.0 \mathrm{~m} \times 1.5 \mathrm{~m}$ \\
\hline 測定部 & $2.0 \mathrm{~m}$ \\
\hline
\end{tabular}

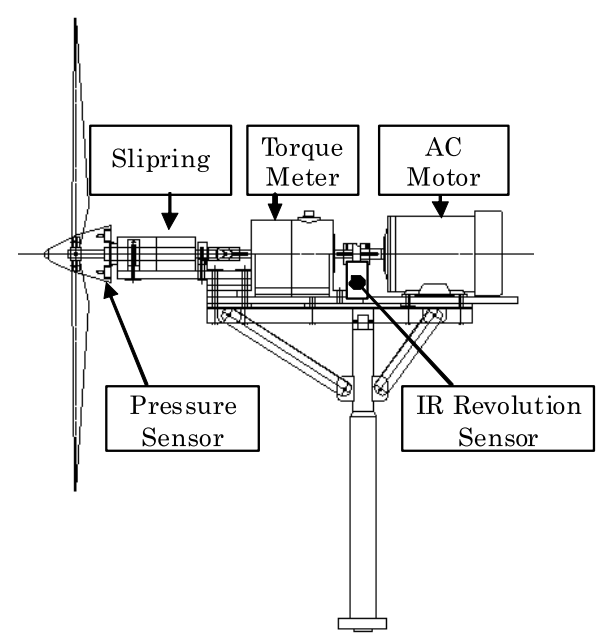

第 4 図 プロペラ駆動装置と各種計測装置

\section{3. 実 験 装 置}

3.1 風洞装置 東海大学航空宇宙学科が所有する低速 風洞試験設備を使用した。風洞の基本性能は第 2 表の通り である. また，同風洞の測定部には 6 分力天秤が備え付け てあり，これを利用してプロペラの推力測定を行った。

3.2 駆動部 第 4 図に示すように, プロペラ回転軸上 に，駆動用のモータ，スリップリング，トルク計を配した。 回転軸は各部で独立しており，軸同士はユニバーサルジョ イントで結合されている。これを第 5 図の写真のように 6 分力天秤上に設置し, 風洞試験部内でプロペラを回転させ た。モー夕の制御は専用のインバー夕を用いて行った。モー 夕回転数の確認は, 回転軸上に貼付した白黒パターンに反 射させた赤外線をフォトダイオードで受光し，ユニバーサ ルカウンターによって行った. プロペラのトルク測定はス リップリング方式のトルク変換器を使用した。

回転系内にあるノーズコーン後部には，ブレード表面の 圧力を測定する圧力センサーが置かれている. 圧力センサー

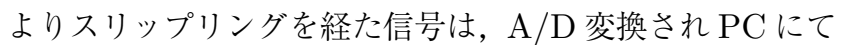
記録される。各装置の系統図を第 6 図に示す。

\section{4. 各種実験装置と実験結果}

4.1 推カ・トルク測定 プロペラブレードの回転による 推力の測定には， 6 分力天秤を使用した。また，トルクは 駆動部に設置されたトルク計を使用し, 動歪計と $\mathrm{A} / \mathrm{D}$ 変 換ボードを通して PCに記録した。データは，サンプリン グレート $0.1 \mathrm{~ms} に 2.5$ 秒間収集し，その平均值とした。 測定した推力とトルクは，第 7 図と第 8 図に示す通りであ る。また，これらから効率を求めたのが第 9 図である。

第 7 図に示した各プロペラブレードについての推力は, 最

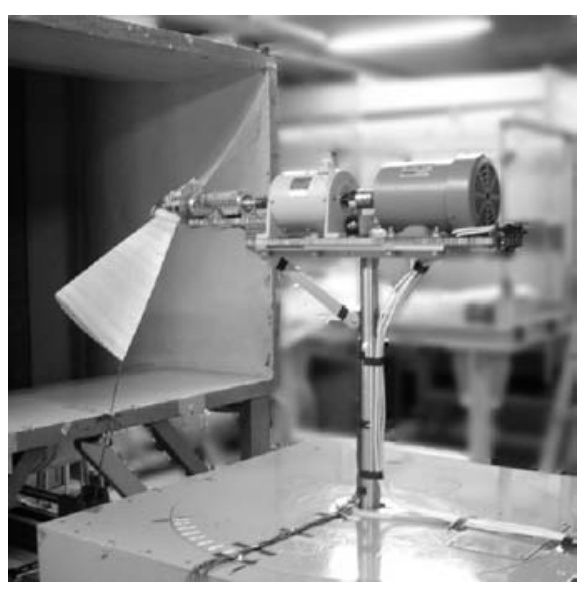

第 5 図＼cjkstart風洞試験部内でのプロペラ駆動装置

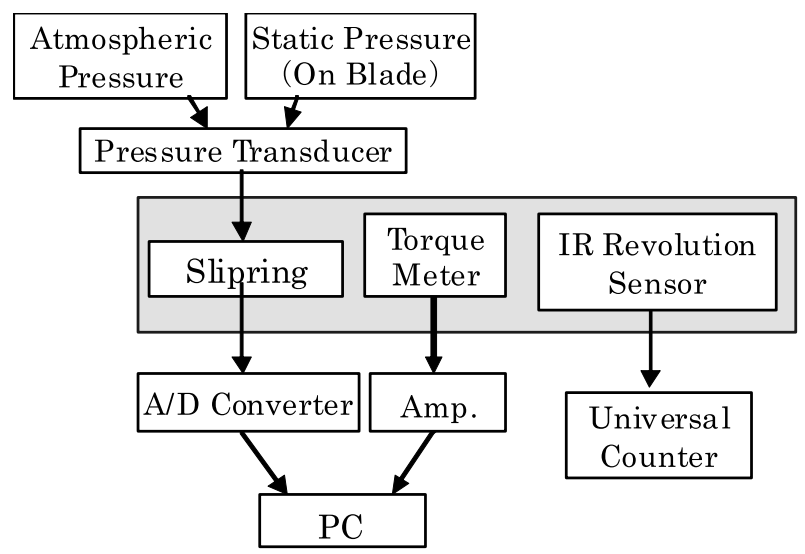

第 6 図 各計測装置系統図

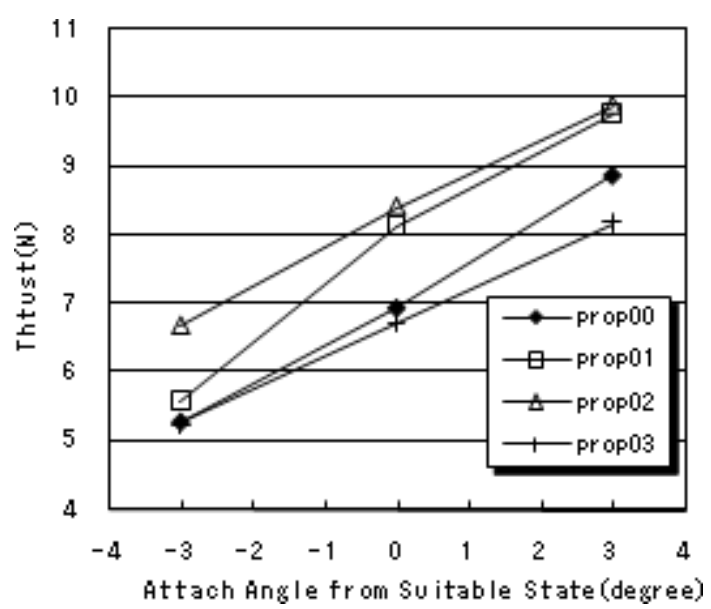

第 7 図 4 種類のプロペラの取り付け角度ごとの推力

適状態での取り付け角を中心として, 取り付け角 3 度増・3 度減に合わせて推力の増減が現れている.ブレードごとに見 れば，ブレード先端の翼弦長が長い逆台形ブレード Prop02 の推力が最も高く，次いで矩形ブレード Prop01, 最適形 状ブレード Prop00, ブレード先端の翼弦長が短い台形ブ レード Prop03 という順になった。一方, トルク測定につ いての第 8 図では，推力と同様に，取り付け角度の増加に 


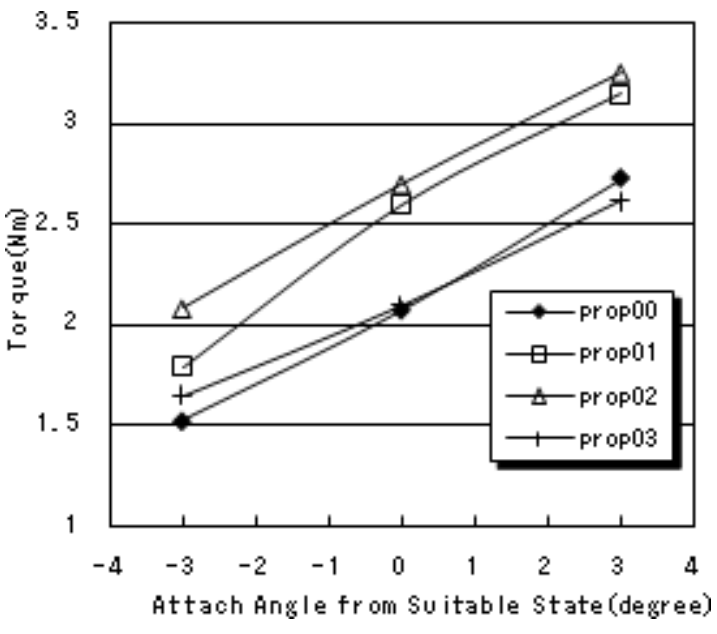

第 8 図 4 種類のプロペラの取り付け角度ごとのトルク

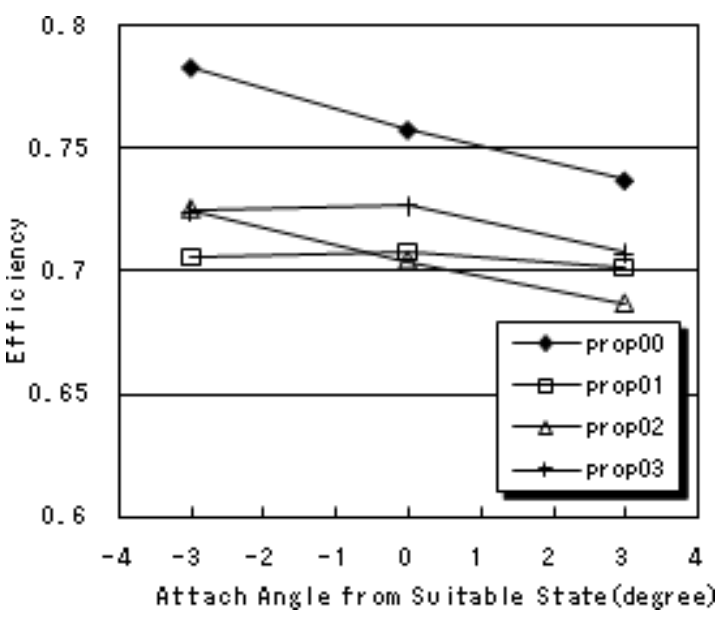

第 9 図 4 種類のプロペラの取り付け角度ごとの効率

よりトルクが増大している様子が分かる．最も高いトルク は逆台形ブレード Prop02 に生じ, 続いて矩形型ブレード Prop01, さらに台形ブレード Prop03, 最適化形状ブレー ドと続いた。

推力・トルク值から求めた効率の分布を第 9 図に示した. プロペラ効率 $\eta$ は, 推力 $T(\mathrm{~N})$, トルク $Q(\mathrm{Nm})$, 進行速 度 $V(\mathrm{~m} / \mathrm{s})$, プロペラの回転角速度 $\omega(\mathrm{rad} / \mathrm{s})$ より，

$$
\eta=\frac{T \cdot V}{Q \cdot \omega}
$$

から得た。効率では, やはり最適形状ブレード Prop00 が 最も高く, 次いで台形型ブレード Prop03, そして矩形ブ レード Prop01 と逆台形ブレードProp02 と続く.ただし, 後者の 2 種類のブレードは取り付け角によって効率が逆転 している.

\section{2 ブレード表面圧力測定}

4.2.1 圧力測定孔 ブレード表面上の静圧を測定するに あたり, 推力・トルク測定などで使用する通常のブレードと は別に，圧力測定を目的とした特殊なブレードを作成した。 第 10 図に示す通り, ブレード表面に, 翼弦方向に 11 点, ブ レード半径方向に 29 点, 従ってブレード片面で 319 点の測

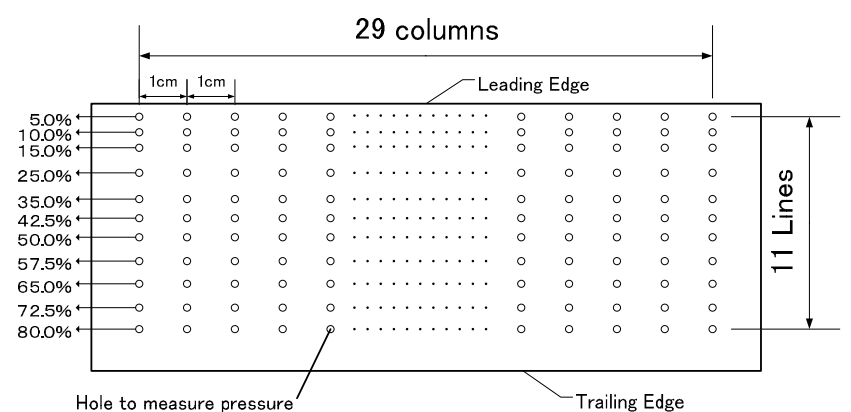

第 10 図 ブレード上圧力測定孔の位置

定用圧力孔を空けた。これらの圧力孔が正圧面のみに空け られたブレードと, 負圧面にのみ空けられたブレードを各々 製作した. 各孔の配置は, 翼弦方向に対しては, 翼弦長に 対し, 前縁から 5.0, 10.0, 15.0, 25.0, 35.0, 42.5, 50.0, $57.5,65.0,72.5,80.0 \%$ の 11 点, またブレード半径方向に 対しては，ブレード回転中心から $10.5 \mathrm{~cm}$ から $38.5 \mathrm{~cm}$ ま で $1 \mathrm{~cm}$ 間隔にて 29 点とした.ブレード翼弦長の $80.0 \%$ よ りも後縁側は, 圧力孔を空けるにはブレード厚さが薄く構 造維持が困難と考え, 測定は行っていない. 本装置に搭載さ れている圧力センサーは 4 個のため，一度に測定できる圧 力は 4 力所のみである. 測定時は, 測定場所の圧力孔にア ルミ管（外径 $1.0 \mathrm{~mm}$, 内径 $0.8 \mathrm{~mm}$ ）を挿入し, シリコン チューブ（外径 $2.0 \mathrm{~mm}$, 内径 $1.0 \mathrm{~mm}$ ）にて圧力センサー と圧力孔を直結することにより，ブレード表面上での圧力 をノーズコーン後部の圧力センサーに伝達した. ブレード 片面における全点の圧力を測定する場合は，このアルミ管 を手動にて 4 本ごとに差し替えた. 測定に用いない圧力孔に は, 圧力孔からの空気の流入出を防ぐために, 直径 $1.0 \mathrm{~mm}$ の円柱型アルミ片を挿入し孔を封鎖した。

4.2 .2 圧カセンサー ブレード表面の圧力測定孔よりシ リコンチューブを経て伝わる圧力は，ノーズコーン後部に 設置した微差圧圧力センサーで測定した。センサー感部の シリコンセンサーによって感知された圧力は, アンプ内蔵 のトランスデューサにより電圧の変化量へと変換され出力 される. 本センサーの測定圧力範囲は $\pm 0.25 \mathrm{kPa}$ である. センサーはゲージ圧を出力するため, 基準圧として大気圧 を必要とする。このため大気圧は, 回転系外, さらに風洞 外より誘導する必要があり, ノーズコーン先端から風洞外 部へ中空の真鍮管を通すことで，大気圧をセンサーへと誘 導した。

4.2 .3 測定手法 圧力測定は，プロペラが回転している 状況下で行った．回転中のブレード表面から伝わる圧力を, ノーズコーン後部の圧力センサーを介し, 電圧変化として $\mathrm{A} / \mathrm{D}$ 変換ボードからコンピュータに記録した. サンプリン グ周波数 $10 \mathrm{kHz}$ にて 2.5 秒間にわたり圧力データを取得 した。この際，同時に収集できる圧力デー夕は，搭載して いる圧力センサーが 4 個のため, ブレード上の 4 点のみで あり, これを各ブレードの片面で 319 点, 両面で 638 点に ついて，測定管を挿し換え 4 点ずつのデー夕取得を繰り返 
した。記録した電圧データはデー夕点ごと平均化し, 校正 デー夕を基に圧力值に変換し，後述の遠心力補正を施した 上で，一様流速による動圧を基にした圧力係数として算出 した.

4.2.4 遠心力補正 ブレード表面の圧力測定孔からノー ズコーン後部の圧力センサーまではシリコンチューブを通 して圧力を伝える。この過程で，プロペラが回転している 場合, チューブ内の空気に遠心力が発生し, 圧力センサー は遠心力に起因する見掛け上の負圧をも感知する。 そこで, 測定された圧力データからこの負圧分を取り除く補正式を 考える.

まず，チューブが一端を中心として角速度 $\omega(\mathrm{rad} / \mathrm{s})$ で 回転しているとした場合, 回転中心から半径 $r(\mathrm{~m})$ だけ離 れた位置での，円管の微小区間 $\mathrm{d} r$ 内の気体に働く遠心力 とそれによる微小圧力 $\mathrm{d} p$ の釣り合いから

$$
\mathrm{d} p=\rho \omega^{2} r \mathrm{~d} r
$$

を得る。ここで $\rho$ は気体密度 $\left(\mathrm{kg} / \mathrm{m}^{3}\right)$ である。また圧力 $p(\mathrm{~Pa})$, 温度 $T(\mathrm{~K})$, 気体定数 $R\left(\mathrm{~m}^{2} / \mathrm{s}^{2} \mathrm{~K}\right)$ とすると, 気 体の状態方程式から $\rho=p / R T$ であるから, 積分により

$$
\ln p=\frac{\omega^{2}}{2 R T} r^{2}+C
$$

となる。ここで $C$ は積分定数である.

遠心力補正は, 半径 $s(\mathrm{~m})$ に位置する圧力センサーから ブレード表面の圧力測定孔までのチューブ内の気体に対し て課すものとして考える. 圧力測定孔は半径 $R(\mathrm{~m})$ の位置 にあり圧力 $P a$ が掛かる。この圧力が真の圧力である. 圧 カセンサーは，ブレードと共に回転するチューブ内の気体 に作用する遠心力による，負圧力が加わった見かけの圧力 $P m$ を感知する. 本補正式ではこの $P m$ から真の圧力 $P a$ を求める。

第 11 図 (a) に示すように, 回転中心から半径位置 $R$ ま で伸びるチューブの外端に圧力 $P a$ が掛かったとすると, 半 径位置 $s$ での, 遠心力の影響を受けた見かけの圧力 $P a^{\prime}$ は

$$
P a^{\prime}=P a \cdot e^{\frac{\omega^{2}}{2 R T}\left(s^{2}-R^{2}\right)}
$$

となる。一方で，第 11 図 (b) に示すように，遠心力の影響 を受けない回転中心での圧力 $P b$ は, 半径位置 $s$ では見か けの圧力 $P b^{\prime}$ となるとして,

$$
P b^{\prime}=P b \cdot e^{\frac{\omega^{2}}{2 R T} s^{2}}
$$

が得られる。

ここで，本実験において遠心力補正を考慮するチューブ の範囲は, 第 11 図 (c) に示すように, 半径 $s$ から $R$ まで の範囲であるから，圧力七ンサーが感知する見かけの圧力 $P m$ は $P m=P a^{\prime}-P b^{\prime}$ となる. 従って真の圧力 $P a$ は

$$
P a=P m \cdot e^{\frac{\omega^{2}}{2 R T}\left(R^{2}-s^{2}\right)}+P b \cdot e^{\frac{\omega^{2}}{2 R T} R^{2}}
$$

から求めることができる.

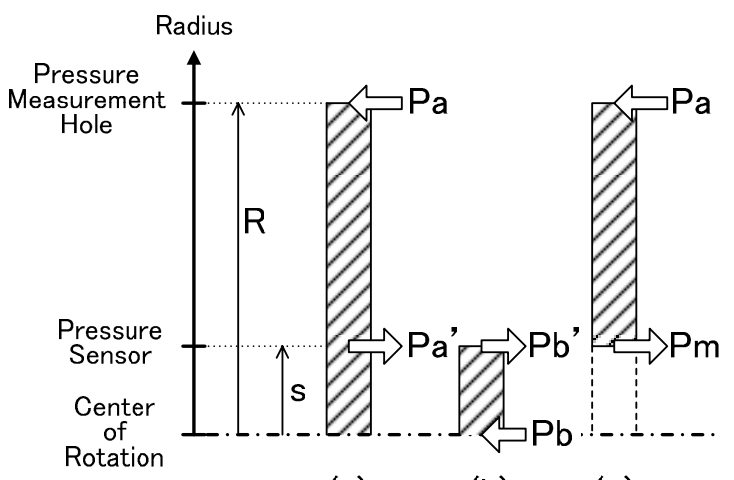

(a) (b)

(c)

第11 図 各圧力のセンサーへの出入り

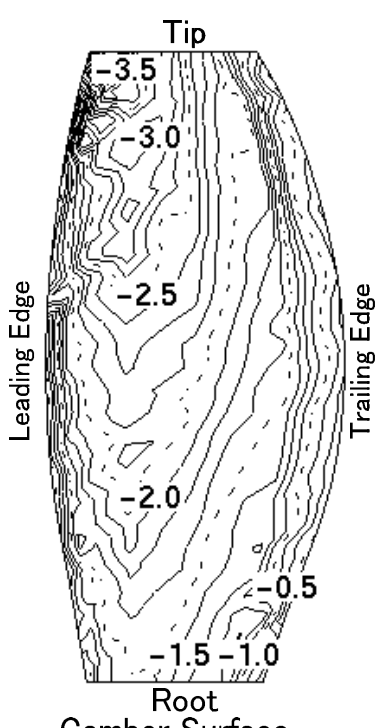

Camber Surface

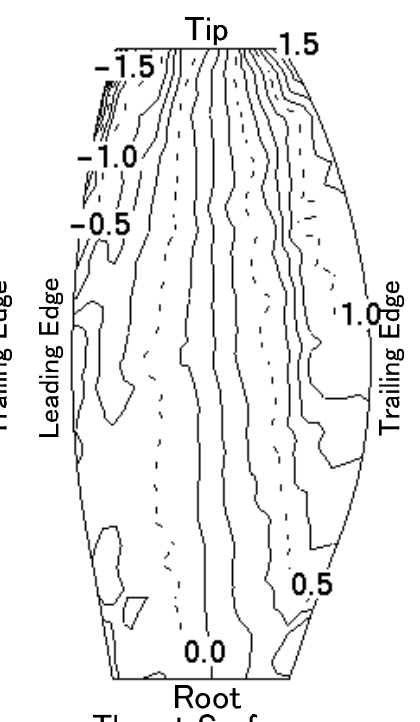

Thrust Surface
第 12 図 Prop00 の圧力係数分布（取り付け角度差 0 度）

4.2 .5 圧力係数分布 第 12 図は標準状態において回転 下にあるProp00 のブレード表面でのキャンバー面とスラ スト面の圧力倸数分布を示している.ブレードの取り付け 角は，最適な角度（取り付け角度 0 度）である. 図中では， 左側がブレードのキャンバー面 (負圧面), 右側がブレード のスラスト面（正圧面）であり，各分布図の右側がブレー ド前縁，上側がブレード端である。また図が示す領域はブ レード全面ではなく, 測定可能範囲（翼弦方向：5～80\%翼 弦長，半径方向：回転中心から $0.105 \sim 0.385 \mathrm{~m}$ ）のみに限 られている。従って, 前後縁・ブレード端と根側の直近は 表示されていない，また，第 13 図では，一様流速と回転数 は維持したまま,ブレードの取り付け角度だけを最適な角 度から 3 度及び -3 度回転させた状態での分布が示されて いる.ささらに, Prop00 以外のブレードでの同様の分布を 第 14 19 図で示した.

第 12 図で示している Prop00 ブレードにおける標準状態 での最適な取り付け角度での圧力係数分布に打いて，キャ ンバー面側では，ブレード半径方向ではブレード端の方が ブレード根側よりも負圧の度合いが高く，また前縁後縁に 沿った部分では，等高線が縁に沿った分布となっており，一 


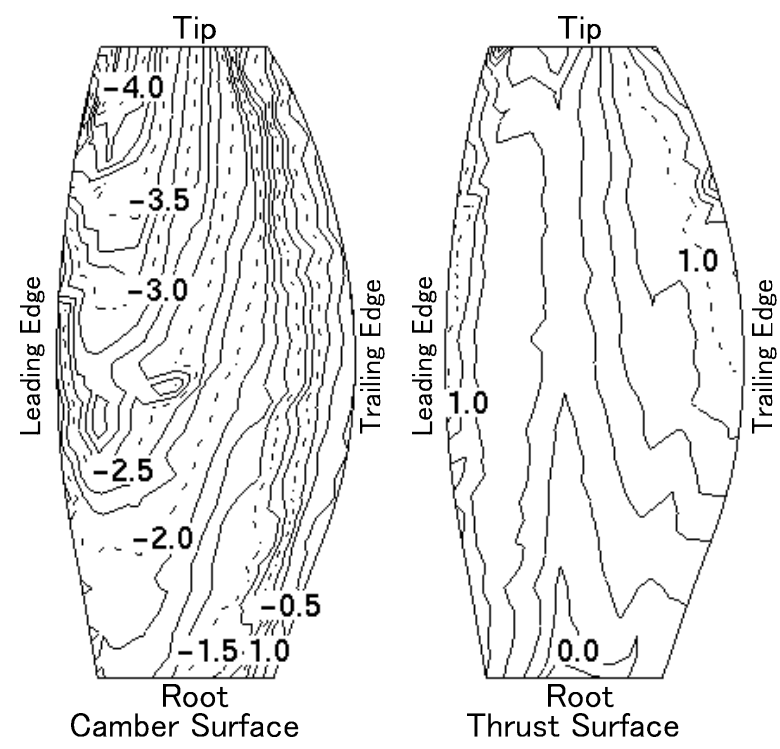

(取り付け角度差 3 度)
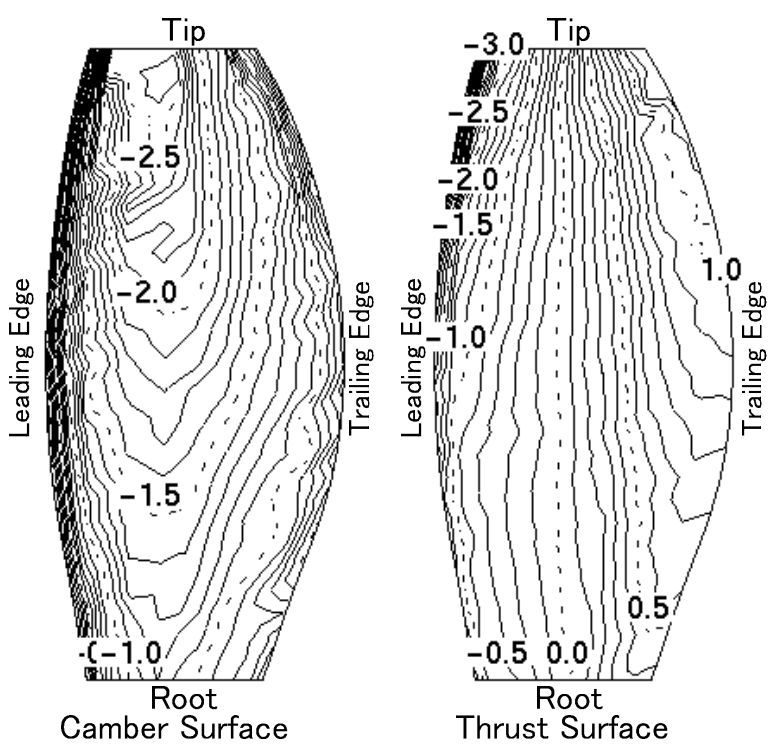

(取り付け角度差 -3 度)

第 13 図 Prop00 の圧力係数分布

方, 翼弦中央付近では半径方向の変化が大きい. 従って, ブ レード端ほど翼弦方向に沿った圧力変化は大きいことが分 かる。 また，ブレード端の後縁付近では，局所的に等高線 の粗密が変化している箇所が見られ, Suction Peak の後 方で流れの剝離と再付着が小規模で発生するショートバブ ル10)の可能性が考えられる．等高線が粗になっている部分 では, 剝離後に死水領域が存在し, また等高線が密になっ ている部分の直後では再付着していると考えられる。キャ ンバー面での最小圧力係数值は -3.78 であった。また，一 方でスラスト面側では, 等高線形状はブレード半径方向に 沿って分布する傾向が見て取れる。

第 13 図では，同じProp00 ブレードでの取り付け角を最 適な角度から 3 度増, または 3 度減じた場合の圧力係数分 布を示した，取り付け角を増した場合では，最適取り付け 角時よりも，全体の分布が前縁側に僅かに移動しているこ とが分かり，また，取り付け角を減じた場合でも後縁側に 移動しているのが分かる. またこれにより, 負圧面の最小 圧力係数值も, 3 度増では $-4.45,3$ 度減では -2.66 とな り最適取り付け角時との変化が現れている。また，上述の ショートバブルと考えられる等高線密度の局所的変化領域 も，取り付け角の増減に伴う迎え角の変化に伴い，それぞ れ前縁方向，後縁方向へ移動しており，ショートバブルの 性質と一致する。

第 14 図及び第 15 図では，矩形型ブレード Prop01 のブ レード表面の圧力係数分布を示した. 全体の分布は Prop00 と同様な傾向となり, 最適取り付け角度では, キャンバー 面での最小圧力係数值は -3.03 である. 取り付け角 3 度増, 3 度減ではそれぞれ $-3.40,-2.50$ となった。ブレード端 後縁での等高線の粗密な局所的な分布の乱れは矩形平面形 状ブレードでも現れた。この粗密な乱れの分布の半径方向 の範囲は Prop00 よりも若干ながら広範囲に広がっている.
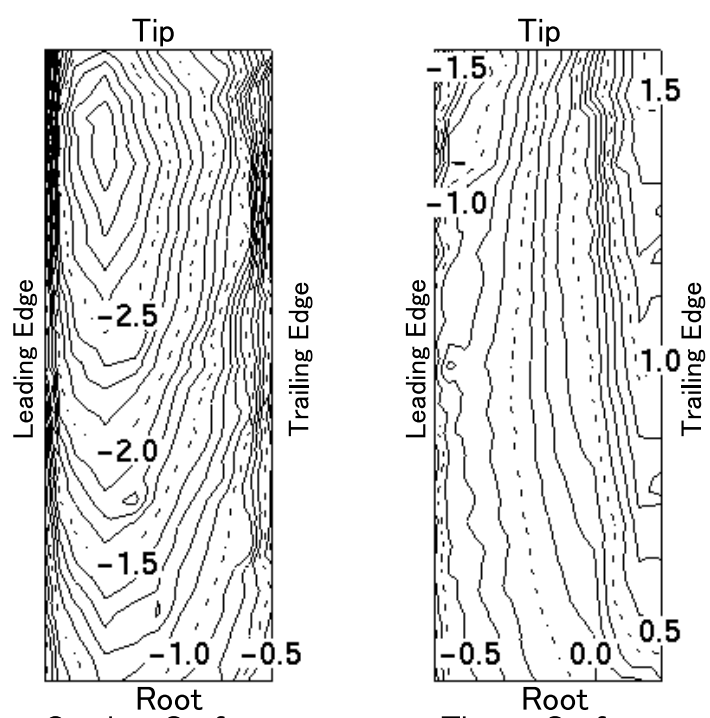

Thrust Surface

第 14 図 Prop01 の圧力係数分布（取り付け角度差 0 度）

第 16，17 図及び第 18，19 図では，それぞれ Prop02, Prop03 ブレードでの圧力係数分布を示す. 最適取り付け 角, 3 度増, 3 度減でのキャンバー面での最小圧力係数 は，Prop02 ブレードでそれぞれ $-3.48,-3.94,-3.26$, Prop03 ブレードで $-4.82,-5.53,-4.04$ となった. $2 つ$ のブレードに扔いても等高線の粗密な分布の乱れは後縁に 見られ，特にProp02では後縁全体にわたってこの分布が 現れた。またProp03ではこの乱れの分布がブレード端ま で延びている.

な㧍，第 20 図に示した分布は，標準状態での Prop00 圧 力分布から, ブレード面の各箇所での法線ベクトルを元に 推力 ·抗力成分に分離し, 求めた効率である. 推力 ·抗力 成分への分離は，ある圧力測定孔で圧力 $p$ が測定されたと 


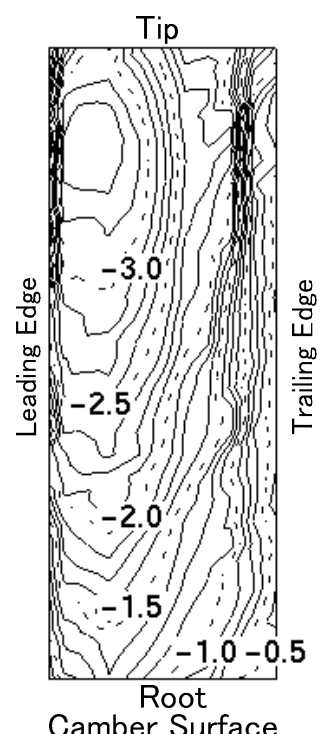

(取り付け角度差 3 度)
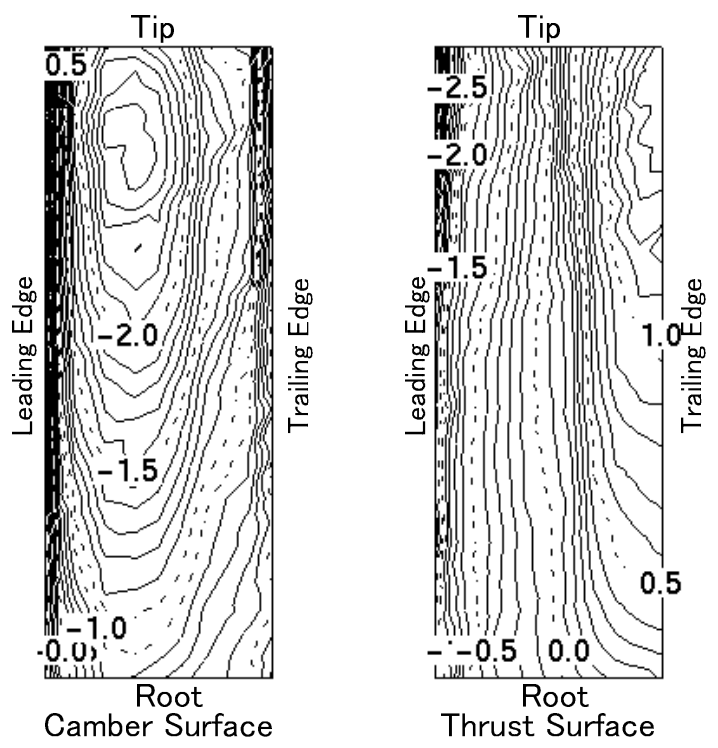

(取り付け角度差 -3 度)

第 15 図 Prop01 の圧力係数分布
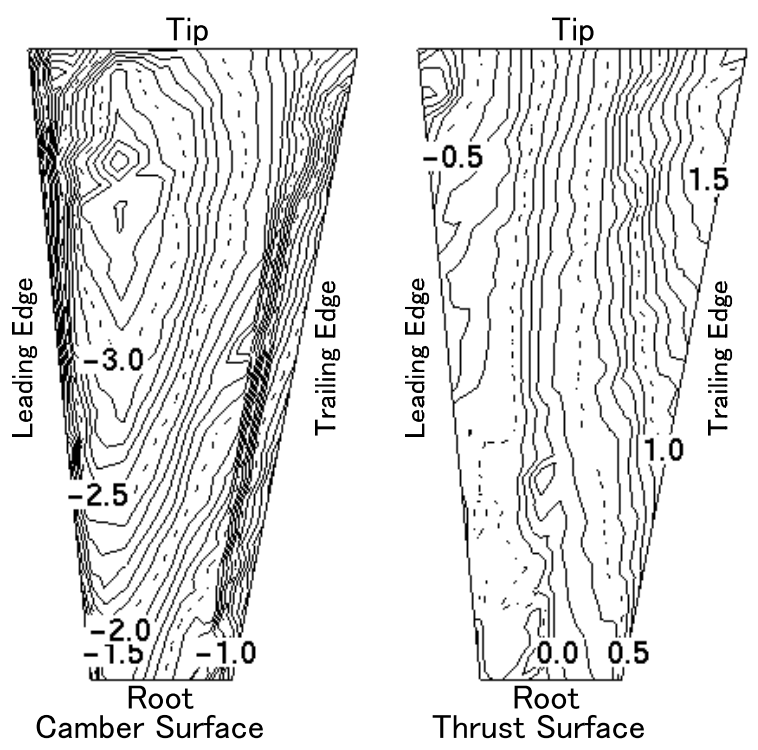

第 16 図 Prop02 の圧力係数分布（取り付け角度差 0 度）

し，その測定孔周辺の面の傾きから代表となる単位法線べ クトル $\vec{n}$ を元に行う. 推力方向の単位ベクトル $\vec{t}$ とトル クの元となる抗力方向の単位ベクトル $\vec{d}$ 上り, 圧力孔周辺 の推力 $T_{\text {local }}$ および抗力 $D_{\text {local }}$ が

$$
\begin{aligned}
& T_{\text {local }}=p s \vec{n} \cdot \vec{t} \\
& D_{\text {local }}=p s \vec{n} \cdot \vec{d}
\end{aligned}
$$

として求まる。ここで圧力孔周辺の代表面積を $s\left(\mathrm{~m}^{2}\right)$ と した。これらのブレード上のすべての圧力孔についての合 計が，圧力による推力と抗力を表す。な扔図中の設計值の 分布はすべて最適状態の値としている. 前述の推力・トル ク測定から得られた効率，及び圧力測定から得られた効率 は，ともに近い值となった。圧力測定による最適取り付け
角での効率が設計值に対して 0.1 高い值を示しており，圧 力分布による測定可能範囲外での影響が考慮されていない ことが原因として考えられる。ただし，圧力分布から得ら れた効率が，設計值及び推力トルク測定值と近い值を示し たことは，測定された圧力係数分布の妥当性を表している ものと考えられる.

\section{3 タフト法によるブレード表面の流れの可視化}

4.3.1 タフト及び撮影法 ブレード表面の流れの状態を 可視化するため, ブレード表面にタフトを貼り付ける表面 タフト法による実験を行った。

回転する物体表面の流れを可視化するためには，油膜法 やタフト法による手法が考えられる。このうち, 油膜法に 関しては，水中用スクリュー表面の流れの可視化で行われ て扔り ${ }^{11)}$ ，遠心力によりオイルが半径方向へ流れる量を定 量的に考察し評価している。 ただし, 実験装置周辺の環境 などを考慮し, 遠心力による油膜の飛散を避ける目的で, 本 実験ではタフト法を用いた。

ここでは，回転下にあるブレード上に貼り付けたタフト の様子を静止画像として撮影するために，発光周期を变え られるストロボを用いた。

すべてのタフトによる可視化実験には，忠実に風向を示 す材料として一般的に使用されている ${ }^{12)}$ 縤りのない日本刺 紼用絹系を用いた。また，カメラによる撮影は露光時間 1 秒, ISO1600, 絞值 $\mathrm{F} 8$ とした. さらに, ストロボ発光周 波数を $1.53 \mathrm{~Hz}(91.7 \mathrm{RPM})$ とし，550 RPM で回転する プロペラに対し 6 回転に 1 回のストロボ発光を行うように した，撮影時は周囲を暗くし，カメラが 1 秒間露光する間 に発光するストロボ光により映し出されたブレード面を撮 影する手法を取った。

また，ブレードの㨝れにより，タフトを貼り付けてある ブレード面は場所によりカメラに対して正対しておらず, 


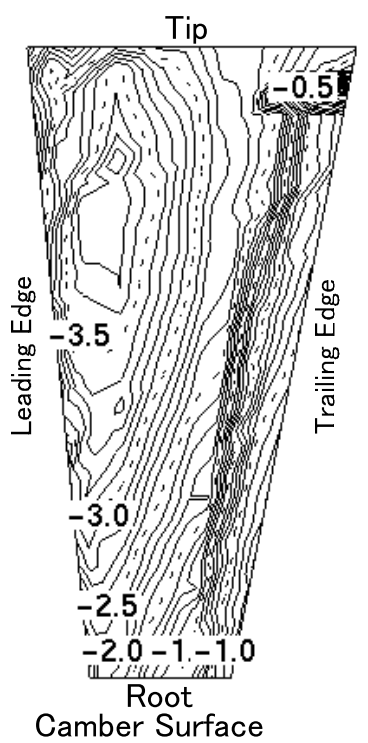

(取り付け角度差 3 度)

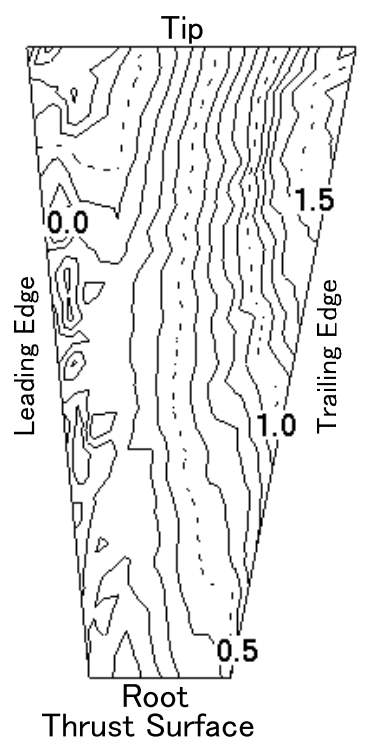

hrust Surface

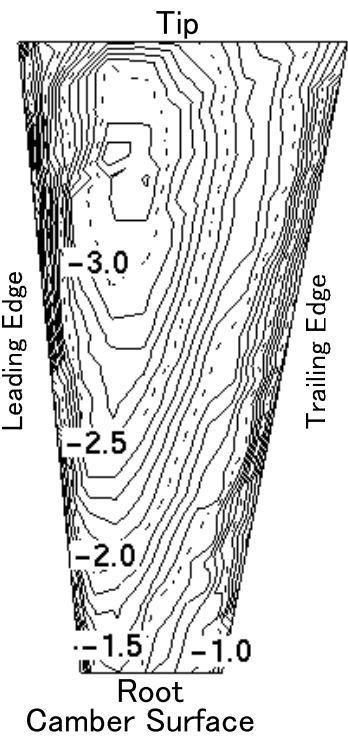

(取り付け角度差 -3 度)

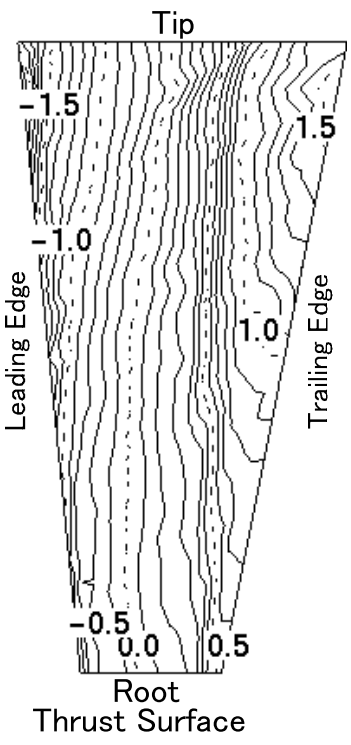

Thrust Surface

第 17 図 Prop02 の圧力係数分布
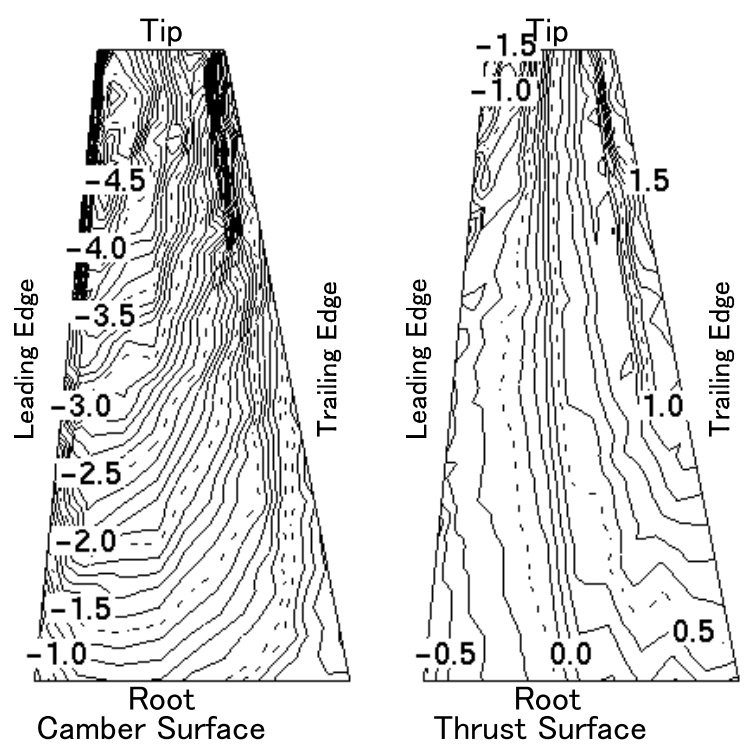

第 18 図 Prop03 の圧力係数分布（取り付け角度差 0 度）

よってタフトの方向を正確に知るためには，撮影されたブ レード面の歪みを考慮する必要がある。従って, 第 21 図 (a) に示すように，プロペラブレードに正方の格子を書き入 れ, タフト貼り付け面のカメラへの歪みの度合も測定した。

4.3.2 回転中の Prop00 表面上でのタフトこの方法 によって撮影された最適形状ブレード Prop00のタフト写 真（第 21 図 (b)）を元にタフトの角度を測り,ブレード 表面の歪み度を加味し, 定量的に評価したタフトの曲げ角 度の分布を示したものが第 22 図である. 図中の左側がブ レードキャンバー面 (負圧面), 右側がスラスト面 (正圧面) を表している，図中では，ブレード表面のタフトの向きを 線で示し, 各円内の数字はタフトと翼弦方向とがなす角度 (degree) を示している. 結果では，まず，キャンバー面・
スラスト面において約 $75 \%$ ブレード半径方向位置を境に夕 フト曲げ角度の特性が変わっている。キャンバー面の半径 方向 $75 \%$ 位置よりブレード根側では，前縁ほどタフトは外 に振れず後縁に近づくにつれ大きく半径方向外側に振れて いる．逆に， $75 \%$ 位置より外側では前縁の夕フトが半径方 向に傾いていても後縁側のものは周方向に向いている. 同 様に，スラスト面に拈いても，僅かであるが似た傾向が現 れている.ブレード半径方向約 $75 \%$ 位置より内側では, 前 縁のタフトが半径方向外側に振れているが，後縁のタフト の振れは前縁ほど外側を向いていない，逆に，75\%位置よ り外側では, 後縁の方が前縁よりもタフトが半径方向外側 を向いている，ただし，この図が示すタフトの曲げ角度に は，タフトに働く遠心力の影響が入っており，遠心力によ る曲げを考慮した実際の風向については, 後述する.

4.3.3 遠心力評価用タフト実験 このタフトに働く遠心 力の影響を評価する。回転下にあるブレード表面のタフト には半径位置に応じ常に遠心力が㗢く. 流れの方向のみを 評価するためには，この遠心力によるタフトへの偏向の影 響を知っておく必要がある。そこで以下の 2 種類の補足実 験を行い，ブレード表面のタフトへの遠心力の影響を計測 した。

遠心力のみによるタフトの偏向の度合を調べるために， 第 23 図に示すように，回転による周速度の流れが影響しな いよう密閉したケースの中にタフトを貼り付け，回転下に おいて遠心力のみの影響を受けたタフトが半径方向に対し 外側を向く角度を撮影した。撮影方法は，ブレード表面の タフト撮影時と同様に，ストロボ発光周期を回転数と同期 させ，カメラの露光の夕イミングから，回転中の試験体が ストロボにより映し出された姿を撮影したものである。試 験体の回転数は実際のブレードと同様の 550 RPM である. 結果を第 24 図に示す。この結果ではタフトの曲げ角度に 


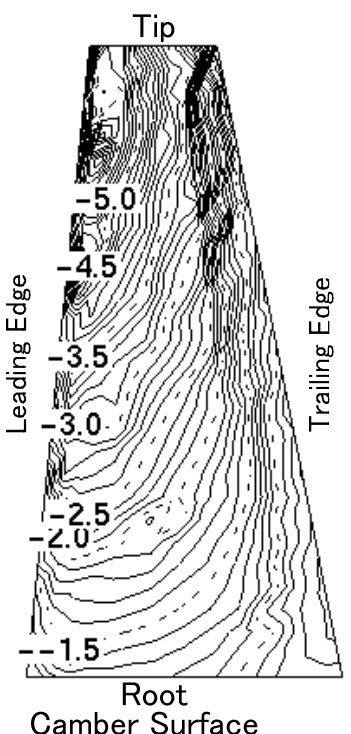

(取り付け角度差 3 度)

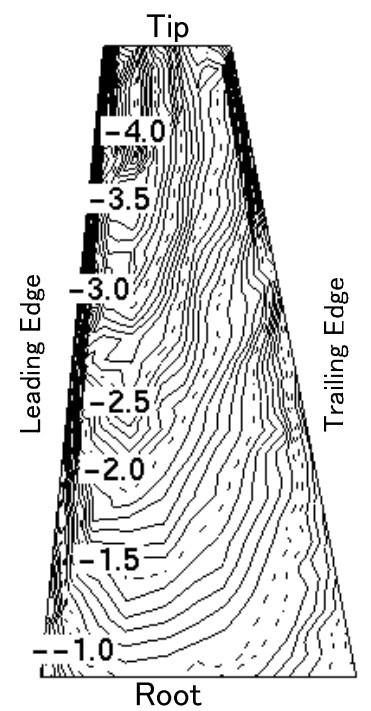

Camber Surface

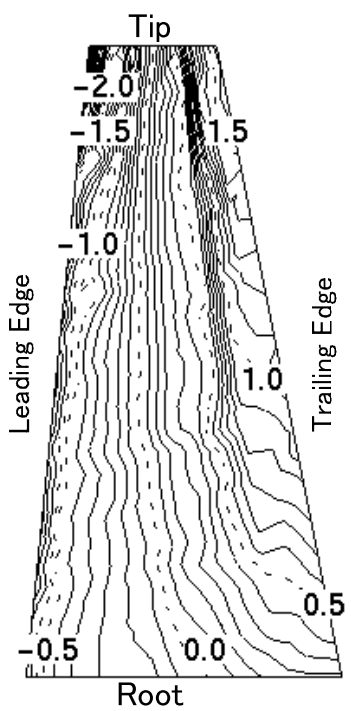

Thrust Surface

(取り付け角度差 -3 度)

第19図 Prop03 の圧力係数分布

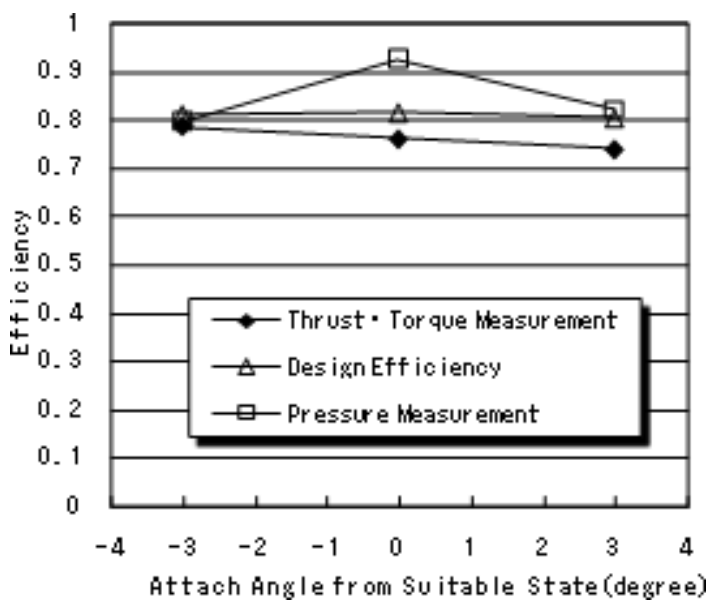

第 20 図 Prop00 ブレードの取り付け角度ごとの効率（推力・トル ク測定，理論式，圧力測定との比較

ばらつきがあるが, 線形近似を行い, 回転中心からの距離 に対して遠心力によるタフトの曲げ角度の関係を決定した。 例えば，回転中心から同位置でこの直線が示す曲げ角度よ りも外に曲がる場合，遠心力以外の外的要因が夕フトに作 用していることが考えられる。

また，回転下にあるブレード面上のタフトは，各ブレー ド半径方向位置での周速度と一様流速（前進速度）による 合成流速度と遠心力の相互作用によりその向きが決まる. ここでは，各ブレード半径方向位置での合成速度に対して， 遠心力による影響がどの程度現れるのかを撮影した。これ も前者の場合と同様に, プロペラと回転数を同じくしスト ロボ発光により映し出された試験体を露光により撮影した. この場合，試験体は，第 25 図に示すように，タフトが貼り 付けられた小型の平板で，このタフトは，遠心力とともに 流れの影響も受けるように外部に露出している。また，実 際のブレードにおいて，半径方向位置の各翼素に流入して

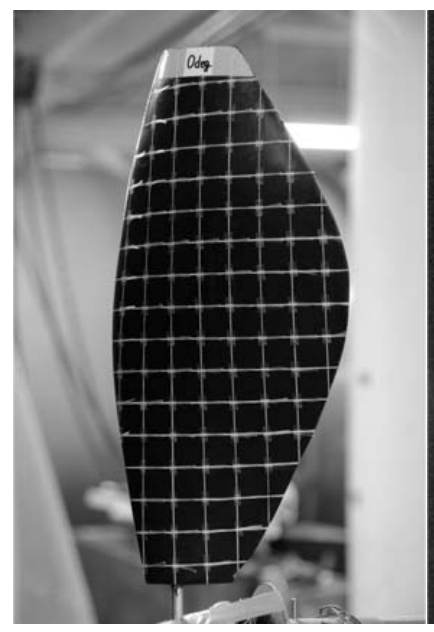

(a) ブレード表面上の格子 (非回転時撮影)

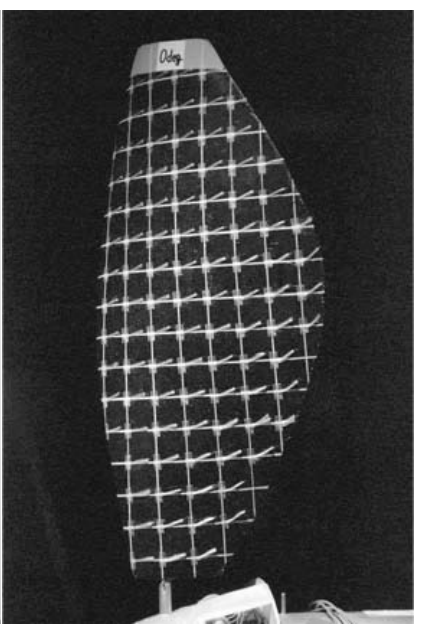
(回転下で撮影) (b) ブレード表面のタフト

第 21 図 Prop00 ブレード表面の格子とタフト

くる合成速度の流入角度は，回転中心からの位置により異 なる。従って，各半径位置に対して，タフトが貼り付けて ある小平板の取り付け角度を，合成流速の流入角度に合わ せた。タフトの撮影は同一半径位置について複数回行い, 各写真から撮影角度を考慮してタフトの角度を測定し, 平 均值を求めた。各半径位置での夕フトの曲げ角度の結果を, 第 26 図に示す。この結果では, 遠心力で半径方向外側に曲 げられたタフトが，流入してくる合成速度によってどれだ け円周方向に戻されるかを見ることができる．図中の曲線 は，各半径位置でのタフト曲げ角度の平均值を多項式近似 したものである。中心から $20 \mathrm{~cm}$ の位置では約 30 度外側 に曲げられ，遠心力のみによる夕フトの曲げ角度と変わら ないが，それより外側では円周方向に大きく戻されている. タフトに使用した経りのない刺紼糸では，中心から $20 \mathrm{~cm}$ 


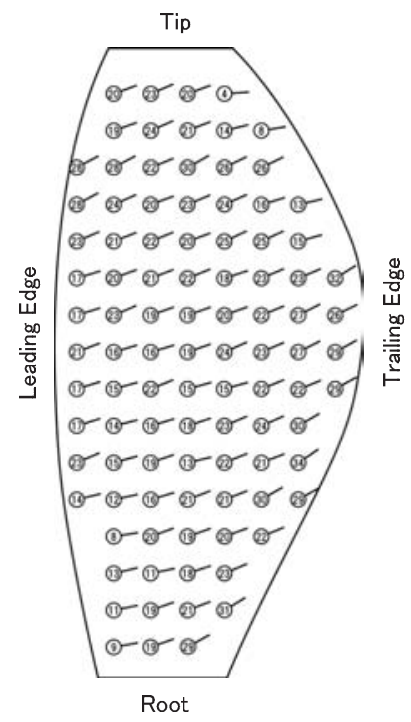

Camber Surface

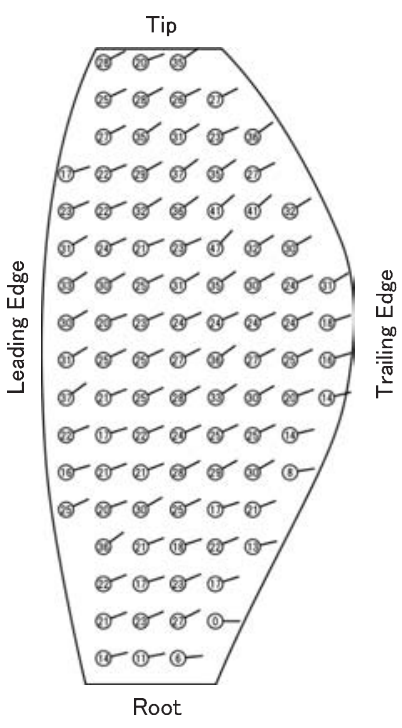

Thrust Surface
第 22 図 Prop00 ブレード表面のタフトの曲げ角度分布

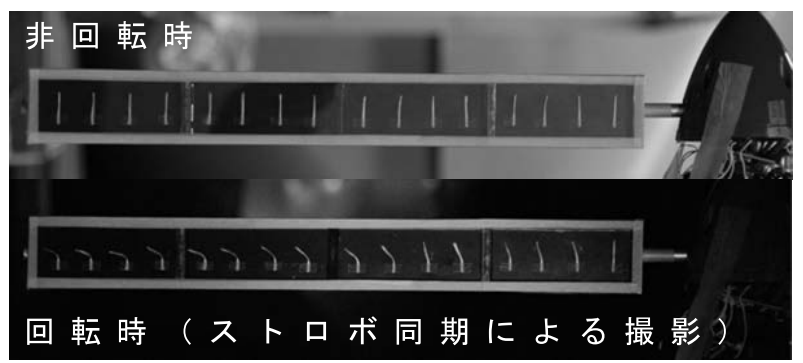

第 23 図 遠心力のみによるタフトの曲げ

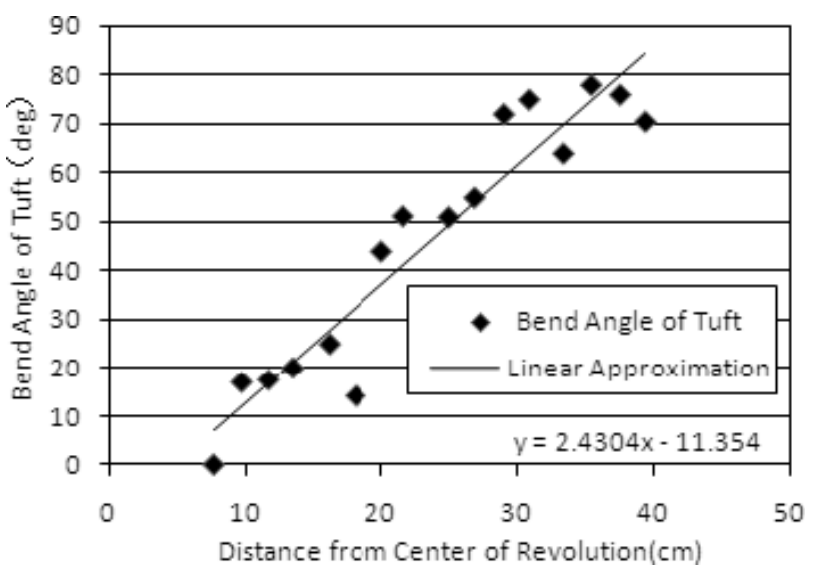

第 24 図 遠心力のみによるタフトの曲げ角度

までは遠心力の影響が大きいものの，その外側では，合成 速度による影響の方が勝りタフトを円周方向へと 20 度弱 まで押し戻す効果が読み取れる。従って，例えばブレード 端において，この角度よりも内側にタフトが曲げられた場 合，遠心力の影響を打ち消す合成流速の向きが，円周方向 よりもさらに内側を向いている，すなわち内側方向への横 流れの発生が可能性として考えられる。

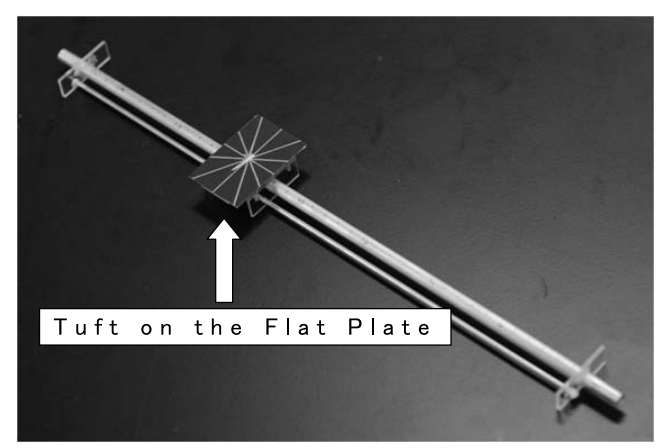

第 25 図 合成速度と遠心力によるタフトの角度測定器具

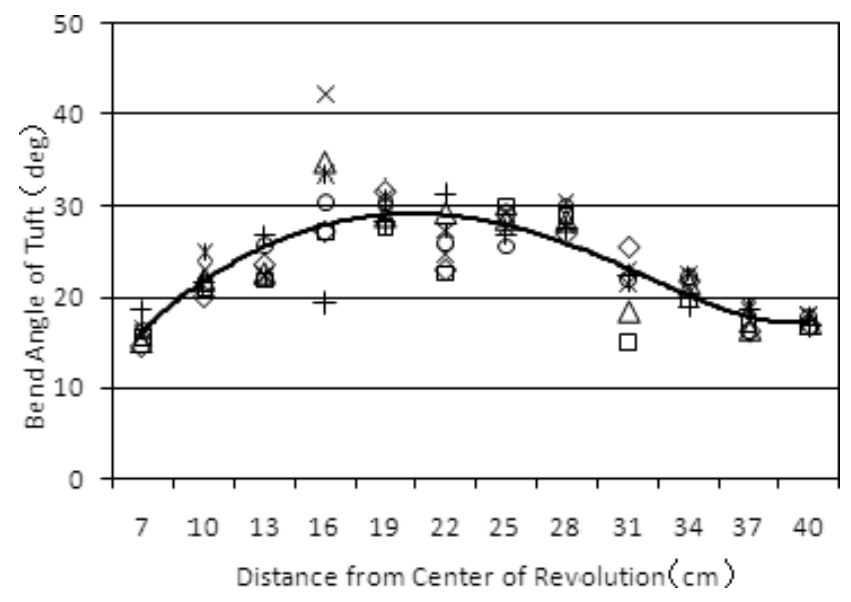

第 26 図 合速度と遠心力によるタフトの曲げ角度 (図中のマーカーは複数回の実験によるデータ)

\section{5. 各実験結果を通しての考察}

5.1 タフト実験 前述の通り, 第 22 図のタフトの曲げ 角度には遠心力による外側方向への曲げの影響も混入して いる，そこで定性的ではあるが，ブレード表面の流れの向 きを，予備実験でのタフトに対する遠心力の影響の結果か ら考察する。

まず，第 22 図に対し，タフトに対する遠心力のみの影響 を調べた第 24 図を用いて，横流れなど遠心力以外の成分の 分離を試みた。第 22 図が示すタフトの曲げ角度が遠心力 のみの影響で半径方向外側に曲げられたタフトよりも，さ らに外側に曲げられた状態は, 明らかに半径方向外側へ向 かう横流れが存在していることを示している。ここで，第 24 図で求めた回転中心からの半径位置に対する遠心力の線 形関係式を用い，遠心力のみによって曲げられるタフトと， 第 22 図で示した実際に回転する Prop00 ブレード表面での タフトの, 曲げ角度の角度差分布を第 27 図に示す。ここで は，実際に回転するブレード上での曲げられたタフトと翼 弦方向のなす角度を $\theta$, 同じ半径位置での遠心力のみによ るタフトの曲げ角度を $\theta_{\text {C.F. }}$ とする。実際のタフトが遠心 力のみのタフトよりブレード半径方向外側に曲げられた場 合は, その角度の差の $\theta-\theta_{\text {C.F. }}$ が正の值となる. 反対に, 実際のタフトの曲げ角度が遠心力のみのタフトの曲げ角度 よりも内側の場合は, その角度の差 $\theta-\theta_{\text {C.F. }}$ は負の值と 


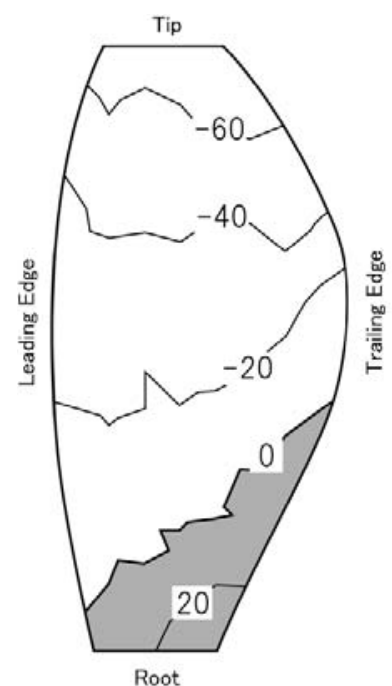

Camber Surface

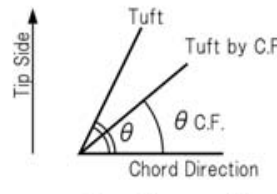

$\theta-\theta$ C.F. $>0$

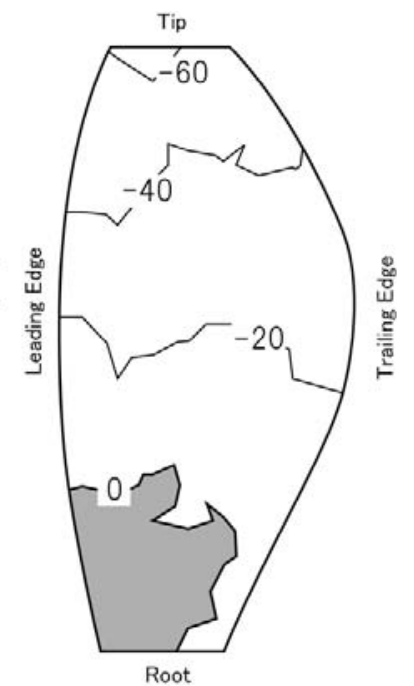

Thrust Surface

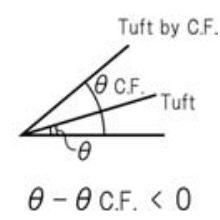

第 27 図 遠心力のみのタフトと Prop00 表面のタフトとの曲げ角度 差分布

なる.

すなわち，図中の灰色で表されている領域のタフトは，遠 心力による影響以上に半径方向外側に振れていたタフトで ある。これらタフトは，遠心力以外の要素の影響を受けさ らに外側を向いていたことが分かる。ここで考え得る要素 はブレード半径方向の横流れであり, 少なくとも上図で示 したブレード端の表面では横流れが発生していると考えら れる。また特にブレードのキャンバー面に执いては，第 22 図について前述の通り, 半径方向 $75 \%$ 位置からブレード根 側の領域では，同一翼弦上であっても前縁側と後縁側で夕 フトの曲げ角度が異なる。従って, これらの結果から, 横 流れはブレード根全体から半径方向 $75 \%$ 位置までの後縁付 近にかけて発生しているものと考えられる。

さらに，回転中心から $36.5 \mathrm{~cm}$ 離れたブレード半径方向 位置での翼素表面では, 遠心力の影響で約 77 度にまで曲げ られるタフトが, 流入してくる合成速度の影響で，曲げ角 度が 20 度弱となり, 内側に戻されることが第 26 図から分 かる。この結果を用いて，第 22 眓のブレードのキャンバー 面での半径方向 $75 \%$ より外側での流れについて考察する. 同領域では, 前縁では 30 度近い外側への曲げ角度が生じて いたにもかかわらず，この位置での後縁のタフトの曲げ角 度はほぼ翼弦方向と差が無い. 第 26 図より, 遠心力と合成 速度の影響を考慮しても, 本来 25 度近く外側へタフトが曲 がるはずである。つまり，ブレードキャンバー面において， ブレード端・後縁部分では急速に半径方向内側に向かう強 い横流れが生じていると考えられる。この流れはブレード
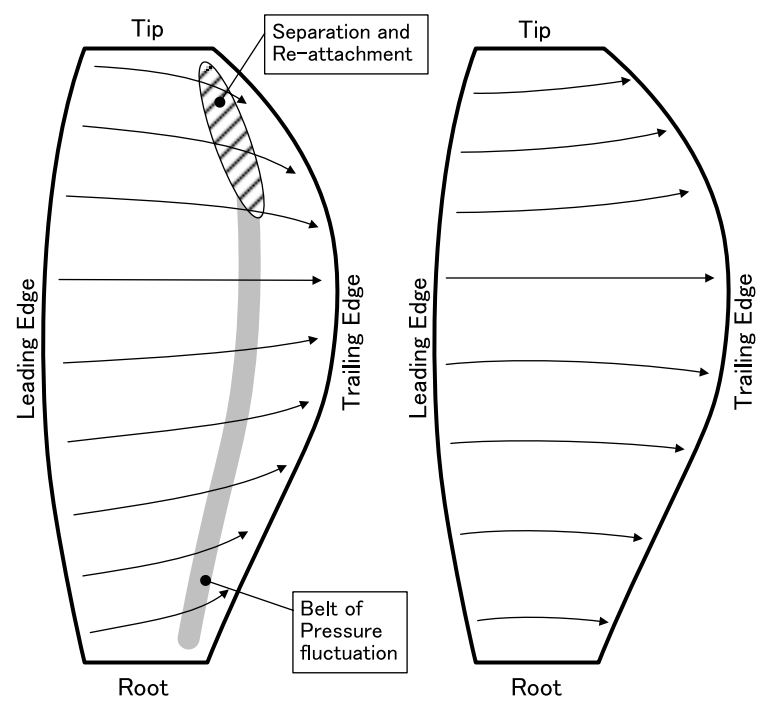

Camber Surface

第 28 図転中の Prop00 ブレード上の流れ（模式図）

端から半径方向 $75 \%$ 位置までの範囲で発生している.

タフト実験により分かった Prop00 ブレード表面上の流 れについて第 28 図で模式的に示した。このときのブレー ド面上での流れは，翼幅の有限な翼に対する流れ13) と同様 であり, 翼端では翼端渦が発生し, キャンバー面では前縁 から後縁に向かうに従いブレード根方向へ，スラスト面で はブレード端方向へ向かう流れが生じる。これらと同様の 傾向は，ブレード半径方向 $75 \%$ より外側の流れに顕著に現 れた。このキャンバー面ブレード端付近での内側への横流 れは，ブレード端での吹き上げによる影響であると言える。 また，ブレードキャンバー面での $75 \%$ 位置より内側での後 縁部分では，半径方向外側への横流れが生じている。これ は後退翼における横流れの発生メカニズムと同じく, 半径 方向外側への翼弦長の急激な増加がブレードキャンバー面 での負圧分布の移動を引き起こし，外側への横流れを誘起 していると考えられる。

ただし，プロペラ回転時，ブレードによる回転面の同心 円方向の円を描く流れとなるため, 同一翼弦線上を流れ抜 ける向きは直線ではなく, 弧を描いていることになる。従っ て，ブレードの前縁からの流入はブレード半径方向外側を 向き，後縁からの流出は半径方向内側を向く傾向があるこ とは考慮しなければならないことを付け加えておく.

5.2 ブレード表面の圧力係数分布と流れ 第 28 図に示 した流れの様子を同ブレードに扔ける標準状態での圧力係 数分布のいくつかの特徵と関連づけて考えることができる.

第 12 図に示した Prop00 の標準状態・最適取り付け角度 での圧力係数分布では, 前述の通り, キャンバー面のブレー ド端・後縁においてショートバブルと考えられる等高線分 布の粗密が乱れている領域が存在した。この領域は, 夕フ トによるブレード表面流れでは，半径方向 $75 \%$ 位置から外 側で発生している，前縁からの流れがブレード半径方向内 側への横流れへと進展する場所と一致していることが分か る。また，ブレードキャンバー面ではブレード後縁に沿っ 
てチップ側からルート側にかけて等高線が密な，すなわち 圧力係数分布の密度が僅かに高い領域が带状に分布してお り，前述のブレード端・後縁でのショートバブルはこの圧 力変動帯上に存在している. 特に, 半径方向 $75 \%$ 位置より 内側では，この圧力変動帯で半径方向外側への横流れが発 生している場所と重なる。

一方，スラスト面では，大部分で等高線がブレード半径 方向を向いているのに対し, 後縁の広い領域では, 後縁に 垂直に等高線が伸びているのが分かる。この傾向は Prop00 だけでなく，その他の 3 つのブレードに対しても同様の傾 向を見ることができる。この部分では翼弦長方向に対して 圧力係数変化がない状態を示しており, 前縁から後縁に向 かって生じている圧力上昇の傾向が消失または緩やかになっ ていると言える。また，この後縁付近での領域の直前では， 僅かながら等高線が密になっていることも確認できる，し かしながら, これらの領域での外側への横流れは発生して おらず，むしろブレード回転に伴う半径方向内側への流出 の傾向の方が強い. 従って, 圧力係数分布に見られたブレー ド後縁一帯における局所的な分布の変動は, ブレード面上 での横流れの発生を表していることが分かる。

また，ブレード端での局所的な剝離・再付着（ショート バブル）は，ブレード端付近に存在する最低負圧部分の下 流で発生しており, その原因は上流での圧力低下から回復 に至る過程でのエネルギー損失にあることが分かる。ただ， この領域はさらにブレード端に接近した位置では消失し, 圧力係数分布の等高線密度は比較的等間隔な分布へと戻る. これは, さらなる翼端近傍で剥離が発生していないことを 意味しており，その原因としては，タフト実験より，翼端 渦発生箇所でのスラスト面から吹き上げられた流れの関与 が考えられる。前縁の最小負圧領域を通過していない流れ が，ブレード端での吹き上げにより後縁に供給され，最も ブレード端に近い後縁での剝離は回避されていると考えら れる.これにより同様に, 他の 3 種のブレードの圧力係数 分布におけるブレード端・後縁部分でのショートバブルの ブレード端への接続が，ブレード端での翼端渦による吹き 上げの強さにより異なっていることが分かる. 第 16 図に示 した Prop02 ブレードは Prop00 に比べて長い翼弦長を有 しブレードも厚いなど強い翼端が発生していると考えられ る。これによりブレード端でのショートバブルは比較的広 い範囲で消失している。たたしこのブレードでは, 後縁全 体にわたり強い圧力上昇带が存在するため, ブレード後縁 全体に強い横流れが存在していると考えられる。一方，第 18 図での Prop03 ブレードでは, Prop02 ブレードとは対 照的に，ブレード端の形状から翼端渦の強さはProp00よ
りも小規模であることがうかがえ，これによりブレード後 縁での圧力変動帯は消失することなくブレード端まで達し ている.

\section{6. 結言}

ブレード表面での直接的な圧力測定では，ブレード後縁 に局所的な圧力の変動帯が存在することが分かった. 特にブ レード端・後縁においては, 剝離・再付着という特徵を持っ た圧力変動が存在していた。また，これに合わせ，Prop00 について，タフト法による流れ方向の可視化実験を行った. タフトに働く遠心力を考慮した上での，ブレード表面での 流れ方向を評価した結果, キャンバー面では, ブレード端か ら内側に向かう横流れと, ブレード根側から外側に向かう 横流れが，後縁一帯に存在していたことが分かった。また， スラスト面ではこれとは逆の傾向の横流れとなっている.

以上のように, 最適化形状手法を用いたプロペラブレー ドに対し，そのブレード表面での流れの様子を，圧力及び タフト実験により解明することができ, 最適ブレード形状 を設計する際に有用な新たな知見となったと考える。

\section{参 考 文 献}

1) Dommasch, D. O., Sherby, S. S. and Connolly, T. F.: Airplane Aerodynamics, Pitman, New York, 1961, pp. 209-215.

2) Rankin, W. J.: On the Mechanical Principles of the Action of Propellers, Trans. Inst. Naval Architects, 6 (1865), pp. 13-39.

3) Froude, R. E.: On the Part Played in Propulsion by Differences of Fluid Pressure, Trans. Inst. Naval Architects, 30 (1889), p. 390.

4) Glauert, H.: The Element of Aerofoil and Airscrew Theory, Cambridge University Press, New York, 1946, pp. 209-221.

5) Glauert, H.: Aerodynamic Theory-A General Review of Progress, Vol. IV. Division L: Airplane Propeller, Dover Publication Inc., New York, 1963, pp. 230-251.

6) Betz, A., with Appendix by Prandtl, L.: Schraubenpropeller mit geringstem Energieverlust, Göttinger Nachrichten, 1919, pp. 193-213.

7) McCormick, B. W.: Aerodynamics, Aeronoutics, and Flight Mechanics, 2nd ed., John Willy \& Sons Inc., New York, 1995, p. 303.

8) Larrabee, E. E.: Design of Propellers for Motorsoarers, NASA CP-2085, Part I, pp. 285-303.

9) Adkins, C. N. and Liebeck, R. H.: Design of Optimum Propellers, AIAA Paper 83-0190, 1983.

10) 李家賢一：翼型上に生ずる層流剝離泡，ながれ， 22 (2003), pp. $15-22$.

11）荒川忠一, 田古里哲夫: 油膜法における油膜パターンの生成機構, その解釈と利用例，流れの可視化， 4, 12 (1984), pp. 17-24.

12）笠木伸英，木村龍治，西岡通男，日野幹雄，保原 充編：流体実 験ハンドブック, 朝倉書店, 東京, 1997, pp. 220-223.

13）牧野光雄: 航空力学の基礎 (第 2 版), 産業図書, 東京, p. 136. 